\title{
Cell-to-Cell Movement of Potexviruses: Evidence for a Ribonucleoprotein Complex Involving the Coat Protein and First Triple Gene Block Protein
}

\author{
Tony J. Lough,, ${ }^{1,4}$ Natalie E. Netzler, ${ }^{1}$ Sarah J. Emerson, ${ }^{1}$ Paul Sutherland, ${ }^{1}$ Fiona Carr, ${ }^{2}$ \\ David L. Beck, ${ }^{1}$ William J. Lucas, ${ }^{1,3}$ and Richard L. S. Forster ${ }^{1}$ \\ ${ }^{1}$ Horticulture and Food Research Institute of New Zealand, Plant Health and Development Group, Private \\ Bag 92 169, Auckland, New Zealand; '2Scottish Crop Research Institute, Invergowrie, Dundee DD2 5DA, \\ U.K.; ${ }^{3}$ Section of Plant Biology, Division of Biological Sciences, University of California, Davis 95616, \\ U.S.A. \\ Accepted 11 May 2000.
}

\begin{abstract}
The triple gene block proteins (TGBp1-3) and coat protein (CP) of potexviruses are required for cell-to-cell movement. Separate models have been proposed for intercellular movement of two of these viruses, transport of intact virions, or a ribonucleoprotein complex (RNP) comprising genomic RNA, TGBp1, and the CP. At issue therefore, is the form(s) in which RNA transport occurs and the roles of TGBp1-3 and the CP in movement. Evidence is presented that, based on microprojectile bombardment studies, TGBp1 and the CP, but not TGBp2 or TGBp3, are co-translocated between cells with viral RNA. In addition, cell-to-cell movement and encapsidation functions of the $\mathrm{CP}$ were shown to be separable, and the ratelimiting factor of potexvirus movement was shown not to be virion accumulation, but rather, the presence of TGBp1-3 and the $C P$ in the infected cell. These findings are consistent with a common mode of transport for potexviruses, involving a non-virion RNP, and show that TGBp1 is the movement protein, whereas TGBp2 and TGBp3 are either involved in intracellular transport or interact with the cellular machinery/docking sites at the plasmodesmata.
\end{abstract}

Viral cell-to-cell movement occurs through plasmodesmata (PD) (Hull 1989; Maule 1991; Lucas and Gilbertson 1994; Carrington et al. 1996), and may utilize two distinct mechanisms. The involvement of virions in this process was learned through early electron microscopy studies of infected tissues in which virions were observed within structurally modified PD (Hull 1989; Robards and Lucas 1990). Such images have been used to explain the mechanism of movement of tubuleforming viruses, such as the como- (van Lent et al. 1990), nepo- (Ritzenthaler et al. 1995), tospo- (Storms et al. 1995), and alfamoviruses (Kasteel et al. 1997; Zheng et al. 1997). Subsequently, molecular studies have revealed the existence

Corresponding author: Tony J. Lough; Current address: Horticulture and Food Research Institute of New Zealand, Plant Health and Development Group, Private Bag 11 030, Palmerston North, New Zealand; Telephone: +64 (6) 3568080 x7797; Fax: +64 (6) 354 6731; E-mail: tlough@hort.cri.nz of viral-encoded proteins essential for cell-to-cell movement. These proteins, termed movement proteins (MPs), have been shown to associate with the PD, increase the PD size exclusion limit (SEL), and interact, in a sequence-nonspecific manner, with viral nucleic acids as well as the host cellular machinery to traffic viral RNA/DNA between cells (e.g., Fujiwara et al. 1993; Noueiry et al. 1994; Heinlein et al. 1995; Ghoshroy et al. 1997; Rojas et al. 1997; Kragler et al. 1998; Lough et al. 1998). Molecular genetic evidence has established that numerous viruses, including tobamo- (Dawson et al. 1988; Saito et al. 1990), diantho- (Xiong et al. 1993); beny- (Quillet et al. 1989), tobra- (Hamilton and Baulcombe 1989), tombus(Scholthof et al. 1993), and hordeiviruses (Petty and Jackson 1989) are competent for cell-to-cell movement in the absence of a functional coat protein (CP). Such studies establish that, for a number of viruses, infection can be propagated via the cell-to-cell transport of a ribonucleoprotein complex (RNP) (Lucas and Gilbertson 1994; Lazarowitz and Beachy 1999).

The CP is pivotal in the infection process, playing a role in replication, virion assembly, and cell-to-cell and long-distance movement. Due to this complexity, it has often proved difficult to elucidate the nature of the infectious material that is being transported through PD. Such a situation is exemplified by the triple gene block (TGB)-containing viruses (potex-, carla-, hordei-, allexi-, fovea-, and benyviruses; van Regenmortel et al. 1999). Based on a requirement for the CP to affect cell-to-cell movement, these viruses can be divided into two groups. Members of the hordei- and benyvirus groups do not require the CP for cell-to-cell movement (Quillet et al. 1989; Petty and Jackson 1989) and, consequently, must have the capacity to move from cell to cell in the form of an RNP, mediated by the TGB proteins (TGBp1, TGBp2, and TGBp3). In contrast, the potexviruses require their $\mathrm{CP}$ to potentiate cell-to-cell movement (Chapman et al. 1992; Forster et al. 1992; Baulcombe et al. 1995). Despite this requirement for the $\mathrm{CP}$ in cell-to-cell movement of potexviruses, the $\mathrm{CP}$ is not an $\mathrm{MP}$, as it does not have the capacity to mediate its own transport, nor that of viral RNA, through PD (Oparka et al. 1996; Lough et al. 1998; Santa Cruz et al. 1998).

Two models have been proposed to account for intercellular potexvirus movement: transport of intact virions or transport 
of a non-virion RNP complex. Support for the involvement of virions in potexvirus movement comes from with using the potexvirus Potato virus $X$ (PVX), the type member of the potexvirus group. Fibrillar material, immuno-reactive with virion-specific antisera, was detected within the PD of PVXinfected tissues (Santa Cruz et al. 1998). In addition, the CP was co-translocated with the infectious material (Santa Cruz et al. 1998). Support for an RNP mode of transport for potexviruses was based on microinjection experiments that employed Escherichia coli-expressed TGBp1 of the potexvirus White clover mosaic virus (WClMV) (Lough et al. 1998). All three TGB proteins (TGBp1-3) and the CP of WCIMV were shown to be required for cell-to-cell movement of fluorescently labeled RNA (Lough et al. 1998). TGBp1, the CP, and viral RNA were shown to be co-translocated between cells. TGBp1 was also shown to possess the capacity to (i) bind RNA in a sequence-nonspecific manner, (ii) increase plasmodesmatal SEL, (iii) traffic itself through PD, and (iv) potentiate the cellto-cell movement of viral RNA in the presence of TGBp2, TGBp3, and the CP (Lough et al. 1998). In the RNP model, the $\mathrm{CP}$ was proposed to act in concert with the TGB proteins to mediate translocation of a complex, consisting of viral RNA, TGBp1, and the CP, into neighboring cells. As this RNP hypothesis was founded on microinjection-based experiments, it is important to note that this method has been challenged on the premise that the injected cell might become traumatized (Storms et al. 1998). As a consequence, these microinjection-based data should be verified by alternative experimental methods.

At issue, therefore, are the transported form and the identity of the viral protein products co-translocated with viral RNA between cells. We have sought to address these questions with both PVX and WClMV. A powerful approach to identify the molecular components involved in the transport of viral RNA has recently been developed (Agranovsky et al. 1998; Itaya et al. 1997; Morozov et al. 1997). In these studies, microprojectile bombardment and transient expression were used to initiate infection. Movement-deficient mutants of PVX could be rescued for cell-to-cell movement following co-bombardment and transient expression of the corresponding wild-type MP introduced on a separate transcriptional unit (plasmid). The use of microprojectile bombardment of PVX clones and proteins provided the opportunity to compare similarities and differences between the roles of TGBp1-3 and the CP of PVX with those reported for WClMV. Furthermore, we sought to obtain additional evidence for or against a virion transport system by the use of mutants of WCIMV. These studies addressed the possibility of uncoupling the processes of virion formation and cell-to-cell movement, and whether or not virion formation is a rate-limiting step in the local spread of viral infection. Our results not only validate those obtained with microinjection, by revealing similarities between the roles of the transport proteins of each virus, but also provide additional evidence in support of a movement model involving an RNP complex comprising genomic RNA, TGBp1, and the CP.

\section{RESULTS}

Rescue of PVX cell-to-cell movement by transient expression of TGB proteins and the CP.

Movement-deficient PVX TGB and CP mutants were generated from a cDNA clone of PVX.GFP-CP placed under the control of the 35S promoter of Cauliflower mosaic virus (CaMV: p35S-PVX.GFP-CP; Fig. 1A). The presence of the green fluorescence protein (GFP) reporter, expressed as a selfcleaving polyprotein, GFP-CP (Santa Cruz et al. 1996), was used to permit the quantitation of PVX cell-to-cell movement. Frame-shift mutations were engineered at the ApaI (position 4949) and XbaI (position 5249) restriction sites of p35SPVX.GFP-CP to create p35S-PVX.GFP $\Delta$ TGB1 and $335 \mathrm{~S}-$ PVX.GFP $\Delta$ TGB2, respectively (Fig. 1A). The mutant p35SPVX.GFPATGB3 was created by mutating the TGB3 start codon from AUG to ACG (Fig. 1A). The CP mutant, p35SPVX.GFP-CP ${ }^{\text {mut2A }}$, defective in the ability to release CP from the GFP-CP polyprotein, does not form virions and cannot move from cell to cell (Santa Cruz et al. 1996). A CPdeficient mutant, p35S-PVX.GFP $\Delta \mathrm{CP}$, was made by deleting 680 nucleotides of the $\mathrm{CP}$ open reading frame (ORF). For this study, sequences encoding PVX TGBp1, TGBp2, TGBp3, or $\mathrm{CP}$ products were inserted into the transient expression vector pRTL2 (Restrepo et al. 1990; Fig. 1B).

Infectivity of p35S-PVX.GFP-CP was confirmed by microprojectile bombardment of mature, detached leaves of Nicotiana benthamiana (Table 1; Fig. 2A). The ability of movement-deficient PVX.GFP-CP mutants to replicate and move from cell to cell was also established. In each instance, mutations within the PVX TGB or CP ORFs resulted in restriction of the virus to the initially bombarded cell (Table 1; Fig. 2D,G; Fig. 3A,D,G). The presence of the GFP reporter allowed us to confirm previous studies showing that each mutant virus was competent for replication, but not for cell-tocell movement (Beck et al. 1991; Chapman et al. 1992; Forster et al. 1992). We next examined the ability of movementdeficient mutants of PVX.GFP-CP to be rescued for cell-tocell movement following co-bombardment with the corresponding wild-type TGB or CP ORF, expressed transiently on a separate plasmid. In each instance, movement-deficient mutants could be rescued, at least to the adjacent cells (Table 1; Fig. 2E,F,H,I; Fig. 3B,C,E,F,H,I; Fig. 4). Indeed, the extent of complementation of PVX.GFP $\Delta$ TGB1, PVX.GFP $\Delta$ CP, and PVX.GFP-CPmut2A showed that p35S-TGB1, or p35S-CP, when transiently expressed, could rescue virus movement well beyond the adjacent cells. Virus movement was extensively rescued within not only the epidermal but also the underlying palisade mesophyll layer. In each instance, GFP fluorescence derived from PVX.GFP $\Delta$ TGB1 (Fig. 2C), or either of the CP mutants, PVX.GFP $\Delta \mathrm{CP}$ and PVX.GFP-CP ${ }^{\text {mut2A }}$ (data not presented), was detected in optical sections collected within the palisade mesophyll layer. Equivalent results were obtained when these experiments were performed with $N$. tabacum (data not presented). These findings are consistent with the studies of Morozov et al. (1997), who demonstrated that a TGB1 mutant of PVX, tagged with the $\beta$-glucuronidase reporter, was rescued by transient expression of p35S-TGB1.

The relative efficiency of cell-to-cell movement of the PVX.GFP $\Delta$ TGB1, PVX.GFP $\Delta$ CP, and PVX.GFP-CPmut2A mutants was determined by performing a series of time-course experiments (Fig. 4). Movement of all mutant viruses was slower, relative to the control PVX.GFP-CP, and this was manifested in two ways. First, the commencement of viral movement within individual infection foci was not synchronous. In control experiments, once initiated, all PVX.GFP-CP 


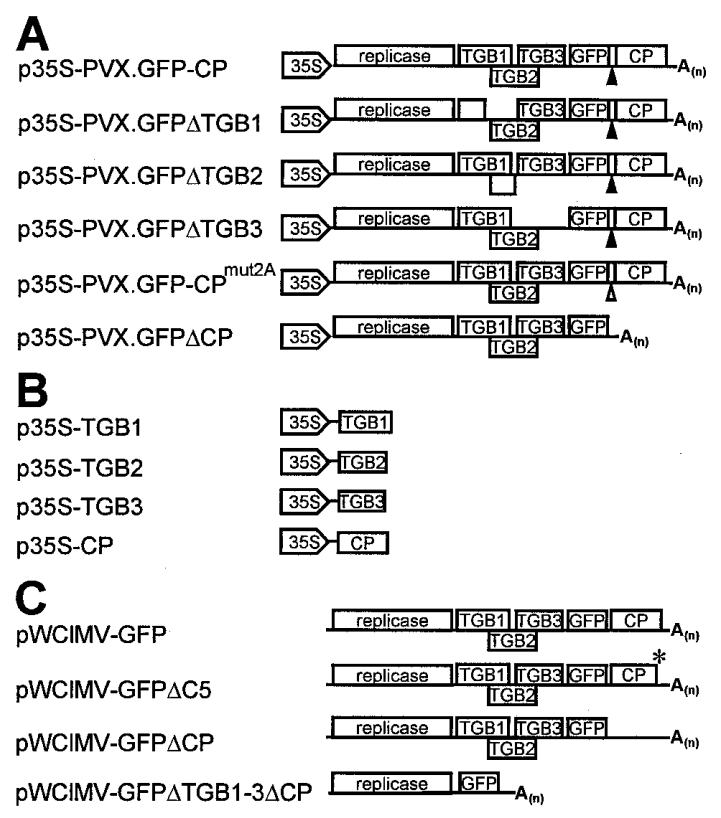

Fig. 1. Wild-type and triple gene block (TGB) or coat protein (CP) mutants of potexviruses Potato virus $X$ (PVX) and White clover mosaic virus (WCIMV) used for infectivity and transient expression studies. Virus movement was quantitated with the use of a green fluorescent protein (GFP) reporter. Genome organization of PVX and WCIMV consists of a replicase and three open reading frames (ORFs; designated as TGB1, TGB2, and TGB3) plus the CP. TGB and CP products are all essential for virus movement. A, Schematic representation of wild-type and movementdeficient mutants of PVX. Infectious clone pTXS-GFP-CP (Santa Cruz et al. 1996) was modified by the addition of the 35S promoter of Cauliflower mosaic virus (CaMV) and was renamed p35S-PVX.GFP-CP. GFP reporter was expressed as a self-cleaving GFP-CP fusion protein (Santa Cruz et al. 1996). Infectious clone p35S-PVX.GFP-CP was used to generate movement-deficient mutants pPVX.GFP $\Delta$ TGB1, pPVX.GFP $\Delta$ TGB2, pPVX.GFP $\Delta$ TGB3, pPVX.GFP $\Delta C P$ and pPVX.GFP-CP ${ }^{\text {mut2A }}$. For a description of mutations engineered into PVX.GFP $\Delta \mathrm{CP}$ and PVX.GFP$\mathrm{CP}^{\mathrm{mut2A}}$ see Baulcombe et al. (1995) and Santa Cruz et al. (1996). Mutants p35S-PVX.GFP $\Delta$ TGB1 and p35S-PVX.GFP $\Delta$ TGB2 were made as frameshift mutations at the ApaI and $X b a \mathrm{I}$ sites within TGB1 or TGB2 ORFs, respectively. Mutant p35S-PVX.GFPATGB3 did not express TGBp3 as the codon initiating translation was modified from AUG to AGG. Arrowheads: positions of foot and mouth disease virus 2A peptide in the translational fusion of GFP to CP. Closed arrowheads: functional 2A sequence that cleaves co-translationally to generate free GFP-2A and CP; open arrowhead: mutant $2 \mathrm{~A}$ sequence, which translates to give a GFP-2ACP fusion protein. B, Schematic representation of transient expression vectors used to rescue cell-to-cell movement of movement-deficient PVX.GFP-CP. Individual ORFs of PVX TGB1, TGB2, TGB3 and the CP were cloned into the transient expression vector pRTL2 (Restrepo et al. 1990). C, Schematic representation of wild-type and movement-deficient mutants of WCIMV. Infectious clone pWCIMV-6 (Beck et al. 1990) was modified by addition of the GFP reporter expressed from a duplicated $\mathrm{CP}$ subgenomic promoter and was named pWCIMV-GFP. Infectious clone pWCIMV-GFP was used to generate mutant pWCIMV-GFP $\Delta \mathrm{C} 5$. A termination of translation codon was engineered within the CP ORF by site directed mutation to truncate the translated product by five $\mathrm{C}$-terminal amino acids. Infectious clone WCIMV-GFP $\triangle \mathrm{CP}$ lacked the duplicated CP subgenomic promoter and consequently could not make a CP product. The remaining $\mathrm{CP}$ ORF was out of frame relative to the translated GFP ORF. Mutant WClMV-GFP $\Delta$ TGB1-3 $\Delta$ CP was generated as a deletion mutant and does not produce TGB or CP products. Bases 4022-5101 and 51955696 were deleted. In this instance bases 5697-5846, including 3' untranslated sequences remained intact. Mutations have been designated as follows: shortened box, frameshift mutations; asterisks, sites of base substitutions; straight lines, mutations that give rise to untranslated regions. infection foci displayed cell-to-cell movement through greater than 20 cells (Fig. 4A). In contrast, in experiments in which transient expression rescued cell-to-cell movement of PVX.GFPATGB1, PVX.GFP $\Delta C P$, or PVX.GFP-CP ${ }^{\text {mut2A }}$, the commencement of viral movement could be either rapid or slow, or the virus could remain restricted to the initially infected cell (Fig. 4B-F). These three patterns were observed in replicated experiments. Second, the relative rate of cell-to-cell movement within infection foci varied. In the wild-type control, PVX.GFP-CP moved from cell to cell such that, within 3 days post bombardment (dpb), the most rapidly spreading foci had already moved through more than 20 cells. Although rescued virus movement was not as efficient as that of PVX.GFP-CP, the movement of mutant PVX.GFP-CPmut2A approached that of PVX.GFP-CP, in that the most rapidly moving infection foci were able to move through more than 20 cells by $3 \mathrm{dpb}$ (compare Figure 4A and F). By contrast, PVX.GFP $\triangle \mathrm{CP}$ and PVX.GFP $\Delta \mathrm{TGB} 1$ required an additional 2 to $4 \mathrm{dpb}$ to move through more than 20 cells (Fig. 4B and E). These results are consistent with a dose-dependent rescue effect in which different infection foci transiently express the required wild-type ORF at different levels. This situation would occur, for example, if there is variation in the proportion of microprojectile particles, coated with the different plasmids in different infection foci.

Co-bombardment of p35S-PVX.GFP $\Delta$ TGB2 with p35STGB2, or p35S-PVX.GFPATGB3 with p35S-TGB3, rescued cell-to-cell movement, but only to the two to eight immediately adjacent cells (Table 1; Fig. 2H,I; Fig. 3B,C; Fig. 4C,D). In both cases, by $10 \mathrm{dpb}$, complementation of movement to adjacent cells had occurred for 41 and $33 \%$ of infection foci, respectively. A number of DNA preparations of p35S-TGB2 and p35S-TGB3 were tested for their ability to rescue cell-tocell movement. Confinement of both PVX.GFP $\Delta$ TGB2 and PVX.GFPATGB3 to adjacent cells is consistent with the hypothesis that neither transiently expressed TGBp2 or TGBp3 nor the encoding mRNA is transported through the PD.

\section{TGBp1 and CP are co-translocated with viral RNA.}

We next tested the hypothesis that rescue of the particular mutant occurred as a result of the co-translocation of the mutant virus with the in planta expressed protein, as opposed to the transport and translation of the plas$\mathrm{mid} /$ transcript. CP from PVX was prepared from virions. Cobombardment of PVX CP with p35S-PVX.GFP-CP ${ }^{\text {mut2A }}$ resulted in the rescue of cell-to-cell movement through as many as 20 cells (data not shown). Collectively, plasmid cobombardment and these data confirm conclusions of Lough et al. (1998) and Santa Cruz et al. (1998), namely that CP is cotranslocated with the infectious material during cell-to-cell movement of potexviruses. Parallel experiments performed with p35S-PVX.GFP $\Delta$ TGB1 and PVX TGBp1, expressed in and purified from $E$. coli, failed to rescue cell-to-cell movement. This likely reflects either an inefficiency in TGBp1 delivery or relative instability of microprojectile-bombarded protein within the target cell.

\section{Virion assembly and cell-to-cell movement are unlinked properties of the CP.}

Previously characterized mutations in the potexvirus $\mathrm{CP}$ cause defects in both cell-to-cell movement and virion assem- 
bly (Chapman et al. 1992; Forster et al. 1992). Here, we used WCIMV CP mutants to test the hypothesis that cell-to-cell movement is a direct function of virion accumulation. The infectious, full-length, cDNA clone, pWClMV-6 (Beck et al. 1990), was modified by duplicating the CP subgenomic promoter sequence (nucleotides 5101 to 5197). The GFP ORF was inserted distal to the duplicated promoter, creating pWCIMV-GFP (Fig. 1C). Movement-deficient CP mutants were engineered in pWCIMV-GFP, from which infectious RNA transcripts were produced. Clone pWCIMV-GFP $\Delta$ C5 was produced by introducing a termination of translation codon that truncated the $\mathrm{CP}$ product by 5 amino acids (Fig. 1C). A second null CP mutant was produced by a frameshift mutation, creating pWCIMV-GFP $\triangle \mathrm{CP}$ (Fig. 1C). The ability of WCIMV-GFP and these CP mutants to replicate and move from cell to cell was examined following mechanical inoculation of infectious transcripts. In contrast to the infection foci that developed on WCIMV-GFP inoculated control plants, the two WClMV CP mutations resulted in the confinement of virus to the initially infected cell (Fig. 5A). The presence of GFP fluorescence established replication competency for each viral CP mutant.

To determine whether WCIMV-GFP $\Delta$ C5 had the capacity to assemble into virions, serum-specific electron microscopy (SSEM; Shukla and Gough 1979) was performed. Virions of WCIMV-GFP $\Delta$ C5 that were morphologically indistinguishable from those of WCIMV-GFP were identified in cellular extracts obtained from inoculated control plants (Tables 2 and 3; Fig. 5A,C). These studies established that the WCIMV-GFP $\Delta$ C5 $\mathrm{CP}$ retained the capacity for virion assembly. Collectively, these experiments suggested that the CP may well have separate roles in virion assembly and cell-to-cell movement.

\section{WCIMV CP mutants rescued by transgenic plant lines expressing wild-type $\mathrm{CP}$.}

We next examined the ability of transgenic $N$. benthamiana plant lines $\mathrm{S} 13$ and $\mathrm{B}_{21}$ expressing the WCIMV CP to rescue the movement of WCIMV-GFP $\Delta \mathrm{C} 5$ and WCIMV-GFP $\Delta \mathrm{CP}$. As CP-mediated resistance has been reported for potexvirus infection on CP-expressing plants (Spillane et al. 1997), it was first necessary to ascertain the impact of this phenomenon on virus movement. To accommodate the effect of local environmental differences, these experiments utilized the apposed half-leaf assay to study the rescue of viral cell-to-cell movement over time (Table 2). No significant difference in the size of the infection foci (Table 2, Fig. 5A) was apparent when plant lines $\mathrm{B}_{21}$ and S13 were inoculated with WCIMV-GFP. Apposed half-leaves were inoculated with WCIMV-GFP and either WCIMV-GFP $\Delta$ C5 or WCIMV-GFP $\Delta$ CP mutants to examine the efficiency of plant lines $B_{21}$ and S13 to rescue cellto-cell movement of these viral CP mutants. At 6 days post inoculation (dpi), infection foci were photographed and measured (Table 2; Fig. 5). These data revealed that statistically equivalently sized infection foci developed on all inoculated half-leaves (Table 2; Fig. 5A). The rate of increase of infection foci was also determined. Infection foci were measured at 4,6 , and 8 dpi, revealing no discernible differences in the rate of virus cell-to-cell movement over time. Quantitative Western blot (immunoblot) analysis established the presence of a fivefold difference in WCIMV CP between plant lines $\mathrm{B}_{21}$ and S13 (Table 2). Thus, the level of CP expressed by plants of line $\mathrm{B}_{21}$ must be sufficient for efficient rescue of viral cell-tocell movement.

\section{Is virion accumulation correlated with rates of cell-to-cell movement?}

Mutations in the potexvirus CP have been shown to result in a marked reduction in the level of plus-sense RNA accumulation in protoplasts (Chapman et al. 1992; Forster et al. 1992). Hence, to ascertain the influence of virion formation on cellto-cell movement, in the present experimental system, it was important to determine (i) the reduction in the level of plussense genomic RNA for the WCIMV-GFP $\Delta$ C5 and WCIMVGFP $\triangle \mathrm{CP}$ mutants, relative to WCIMV-GFP, and (ii) whether this reduction was equivalent for the two $\mathrm{CP}$ mutants. Consistent with previous studies with protoplasts (Chapman et al. 1992; Forster et al. 1992), Northern (RNA) blot analyses revealed that, relative to WCIMV-GFP RNA levels, plus-sense genomic RNA levels for both WCIMV-GFP $\Delta$ C5 and WCIMV-GFP $\triangle$ CP equivalently underwent an approximately 10-fold reduction (R. L. S. Forster and D. L. Beck, unpublished data).

Table 1. Rescue of movement-deficient PVX.GFP-CP in leaves of Nicotiana benthamiana co-bombarded with the corresponding wild-type gene

\begin{tabular}{|c|c|c|c|c|}
\hline \multirow[b]{2}{*}{ Plasmids used in transient expression assays } & \multicolumn{4}{|c|}{ Infection foci $(\%)^{a}$} \\
\hline & 1 cell & $2-8$ cells $^{b}$ & 9-19 cells & $20+$ cells \\
\hline p35S-PVX.GFP-CP & $0(0)$ & $0(0)$ & $74(2)$ & $2,992(98)$ \\
\hline p35S-PVX.GFP $\Delta$ TGB1 & $594(100)$ & $0(0)$ & $0(0)$ & $0(0)$ \\
\hline p35S-PVX.GFP $\Delta$ TGB1 + p35S-TGB1 & $1,127(21)$ & $2514(46)$ & $1,614(30)$ & $178(3)$ \\
\hline p35S-PVX.GFP $\Delta$ TGB2 & $884(100)$ & $0(0)$ & $0(0)$ & $0(0)$ \\
\hline p35S-PVX.GFP $\Delta$ TGB2 + p35S-TGB2 & $319(59)$ & $223(41)$ & $0(0)$ & $0(0)$ \\
\hline p35S-PVX.GFP $\Delta$ TGB3 & $1,436(100)$ & $0(0)$ & $0(0)$ & $0(0)$ \\
\hline p35S-PVX.GFP $\Delta$ TGB3 + p35S-TGB3 & $543(67)$ & $265(33)$ & $0(0)$ & $0(0)$ \\
\hline p35S-PVX.GFP $\Delta C P$ & $685(100)$ & $0(0)$ & $0(0)$ & $0(0)$ \\
\hline p35S-PVX.GFP $\Delta C P+$ p35S-CP & $208(22)$ & $433(43)$ & $243(25)$ & $96(10)$ \\
\hline p35S-PVX.GFP-CPmut2A & $1,041(100)$ & $0(0)$ & $0(0)$ & $0(0)$ \\
\hline p35S-PVX.GFP-CP ${ }^{\text {mut2A }}+$ p35S-CP & $182(12)$ & $289(20)$ & $634(43)$ & $364(25)$ \\
\hline
\end{tabular}

a Data recorded at 7 days post bombardment.

${ }^{\mathrm{b}}$ Average numbers of adjacent epidermal cells in our experimental material were determined with the lipophilic dye FM1-43. There was a range of 4 to 8 epidermal cells directly connected on the upper (adaxial) surface of mature $N$. benthamiana leaves (the average and standard error were determined as $6 \pm 1.0$ ). Foci of 8 cells or fewer were therefore considered to be movement to the adjacent cell only. 
If virion accumulation is correlated with the rate of cellto-cell movement, then each of the WCIMV CP mutants should accumulate virions at a rate approximately 10-fold lower than wild-type WClMV-GFP. This hypothesis was tested by excising and pooling 10 infection foci from leaves inoculated with WCIMV-GFP or each of the two CP mutants. Based on leaf-dip analyses (Hitchborn and Hills 1965), virions were readily detected in control and transgenic leaf tissue infected with WCIMV-GFP (Table 3). Viri- ons formed by WClMV-GFP $\triangle \mathrm{CP}$ were difficult to find in $\mathrm{B}_{21}$ tissues and were not detected by this method in S13 tissues, despite the fact that large infection foci were clearly evident (Fig. 5A; Table 2). In this case, the observed low level of virion accumulation reflects the situation that assembly can only occur with the CP expressed by the transgenic plant. Larger numbers of virions of WCIMV-GFP $\Delta \mathrm{C} 5$ were detected in samples obtained from transgenic, but not control, tissue (Table 3); this likely reflects virion assembly
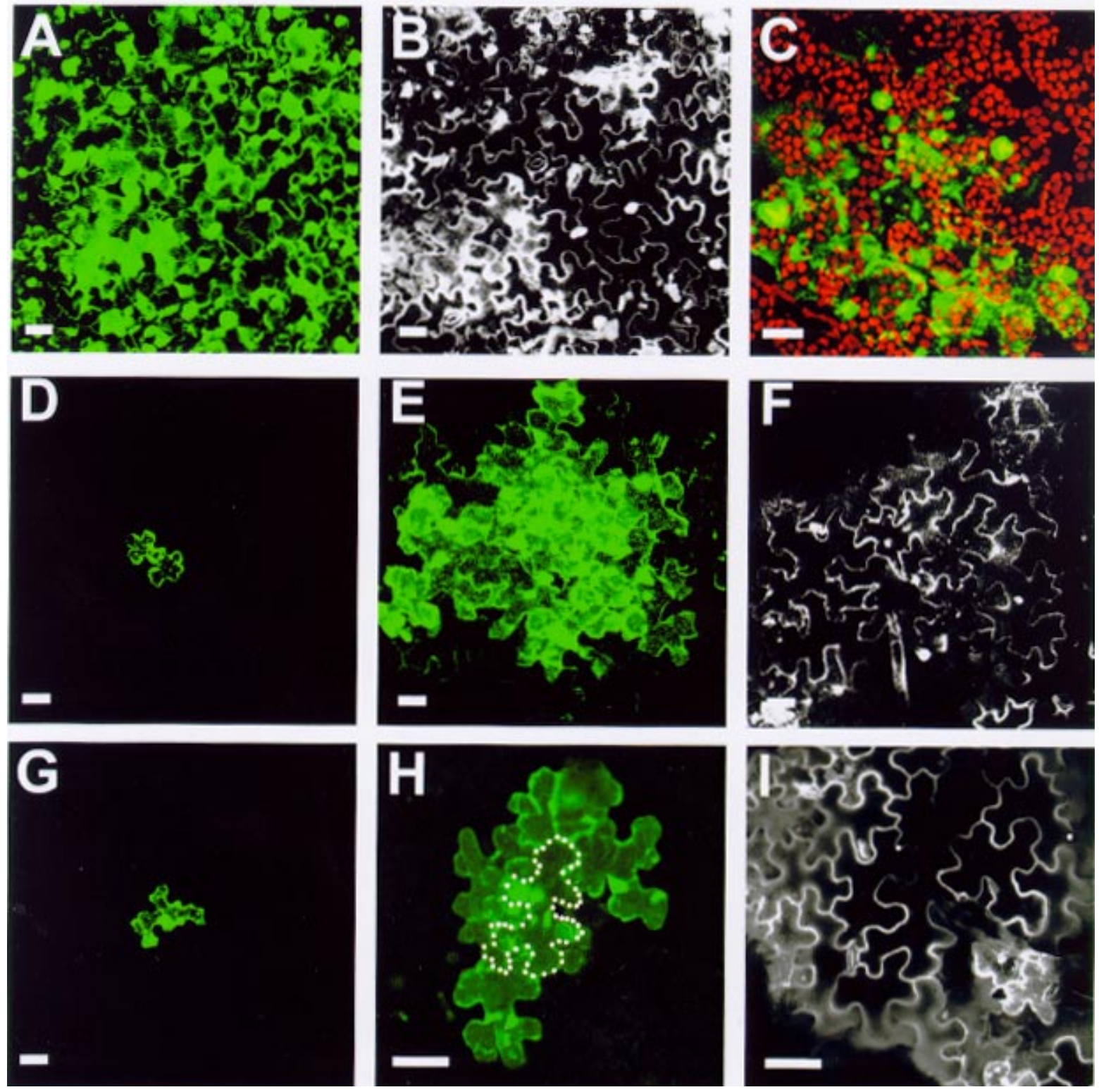

Fig. 2. Cell-to-cell movement of wild-type or movement-deficient mutants of PVX.GFP-CP between mature epidermal or mesophyll cells of Nicotiana benthamiana. Microprojectile bombardment was used to initiate virus infection and all images were collected 7 days post bombardment. A Leica TCS-4D upright confocal laser scanning microscope was used to image cells. Fluorescence intensities are presented in false color; images are composed of 5-10 optically stacked sections. Green fluorescent protein (GFP) is absent within the symplasmically isolated guard cells. Scale bars $=50 \mu \mathrm{m}$. A, Infection initiated with p35S-PVX.GFP-CP spreads rapidly to many cells. Cellular arrangement of epidermal cells, from same field of view seen in (A) gained by applying lipophilic dye FM 1-43 to surface of cells adjacent to the initially bombarded cell. C, Cell-to-cell movement of PVX.GFP $\Delta$ TGB1 was rescued by co-bombardment with p35S-TGB1 into underlying palisade mesophyll cells. D, Infection initiated with p35S-PVX.GFP $\Delta$ TGB1 remained restricted to initially bombarded cell. E, Cell-to-cell movement of PVX.GFPATGB1 was rescued by co-bombardment with p35S-TGB1 well beyond the adjacent cell. F, Cellular arrangement of epidermal cells, from the same field of view seen in $(\mathbf{E})$ as described above. G, Infection initiated with p35S-PVX.GFP $\Delta$ TGB2 remained restricted to initially bombarded cell. H, Cell-to-cell movement of PVX.GFPATGB2 was rescued to the adjacent cells from the likely initially infected cell (highlighted) by cobombardment with p35S-TGB2. I, Cellular arrangement of epidermal cells, from same field of view seen in $(\mathbf{H})$ as described above. 
with both the virally expressed mutant $\mathrm{CP}$ and the wild-type $\mathrm{CP}$ expressed by the transgenic plant.

In view of the limited sensitivity of the leaf-dip assay, analysis of virion accumulation was repeated, on the same extracts, with the more sensitive technique of SSEM (Table 3). Accumulation of WCIMV-GFP, as determined by SSEM, reflected, in proportion, the leaf-dip assays (Table 3). Whereas, with the leaf-dip assay, virions were rarely detected in $\mathrm{B}_{21}$ tissues infected by WCIMV-GFP $\Delta \mathrm{CP}$, and not at all in S13-infected samples, low levels could be observed by the SSEM technique. Relative to WCIMV-GFP, the level of WCIMV-GFP $\triangle \mathrm{CP}$ virion accumulation in $\mathrm{S} 13$ and $\mathrm{B}_{21}$ tissues was reduced by 60 - and 350 -fold, respectively (Table 3 ). Interestingly, these values are considerably lower than the approximately 10-fold reduction seen in plus-sense genomic RNA levels. Similar SSEM analyses performed on infection foci extracted from WCIMV-GFP $\Delta \mathrm{C} 5$ inoculated plants revealed only a two- to threefold reduction in the level of virion accumulation, compared with WCIMV-GFP (Table 3). These data clearly indicate that WCIMV-GFP $\Delta \mathrm{C} 5$ must undergo efficient virion formation. In addition, these experiments indicate that potexvirus cell-to-cell movement is not a simple function of either steady-state, plus-sense genomic RNA levels or of virion accumulation. Furthermore, the level of virion
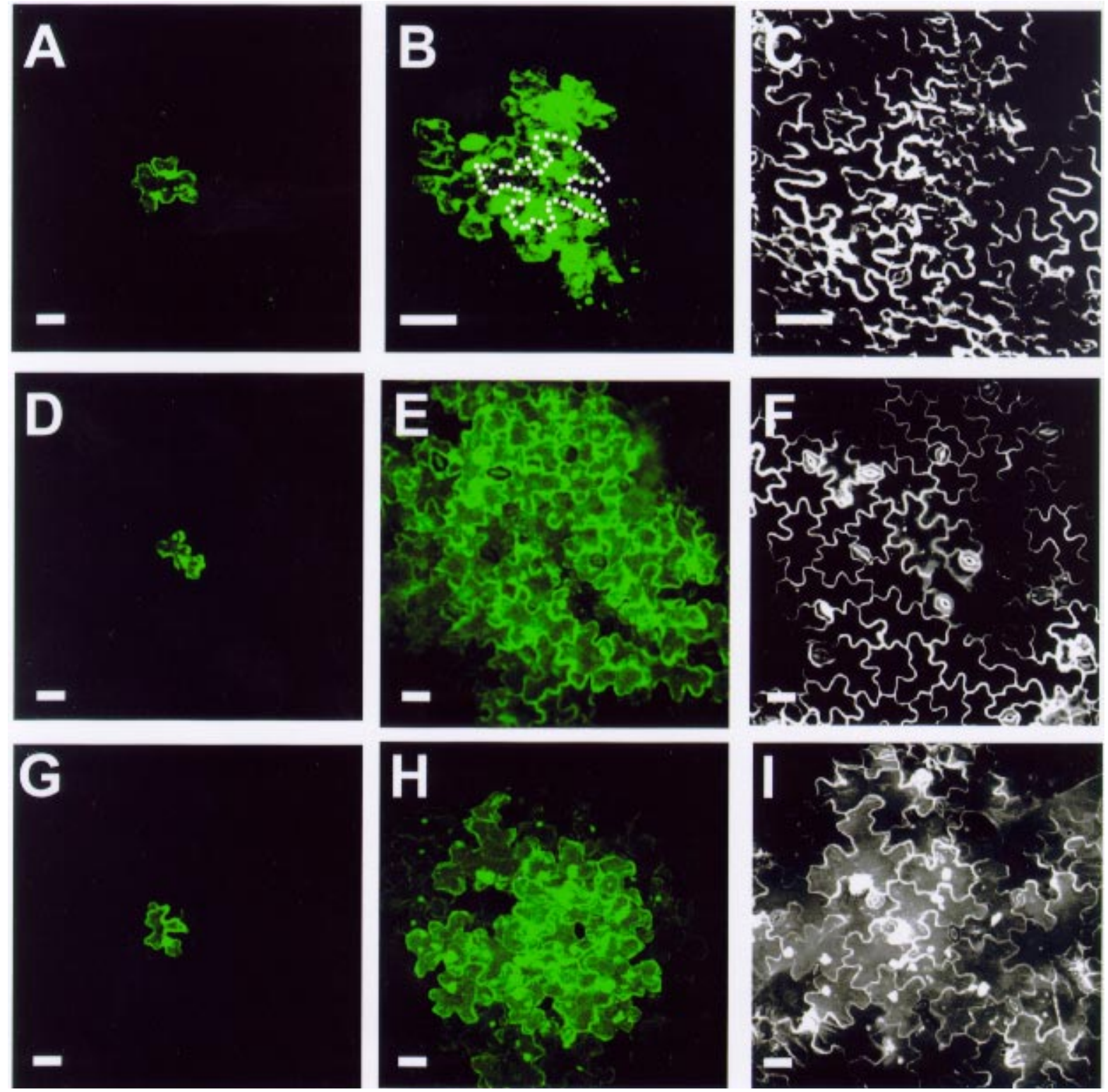

Fig. 3. Cell-to-cell movement of wild-type or movement-deficient mutants of PVX.GFP-CP between mature epidermal cells of Nicotiana benthamiana. Experimental details as described for Figure 2. Scale bars represent $50 \mu \mathrm{m}$. A, Infection initiated with p35S-PVX.GFP $\Delta$ TGB3 remained restricted to initially bombarded cell. B, Cell-to-cell movement of PVX.GFP bombardment with p35S-TGB3. C, Cellular arrangement of epidermal cells, from same field of view seen in (B) as described above. D, Infection initiated with p35S-PVX.GFP $\triangle$ CP remained restricted to initially bombarded cell. E, Cell-to-cell movement of PVX.GFP $\Delta$ CP was rescued by co-bombardment with p35S-CP well beyond adjacent cell. F, Cellular arrangement of epidermal cells, from same field of view seen in (E) as described above. G, Infection initiated with p35S-PVX.GFP-CP ${ }^{\text {mut2A }}$ remained restricted to initially bombarded cell. H, Cell-to-cell movement of PVX.GFP-CP ${ }^{\text {mut2A }}$ was rescued by cobombardment with p35S-CP well beyond adjacent cell. I, Cellular arrangement of epidermal cells, from same field of view seen in $(\mathbf{H})$ as described above. 
accumulation of WCIMV-GFP $\Delta$ CP, as determined by SSEM (Table 3), clearly indicates that WCIMV-GFP $\Delta$ CP accumulated largely in a non-virion form.

\section{Enhanced movement in transgenic plant lines} expressing the TGB and CP.

The SSEM studies revealed that, even in the absence of a functional $\mathrm{CP}$, virion accumulation could be greatly reduced
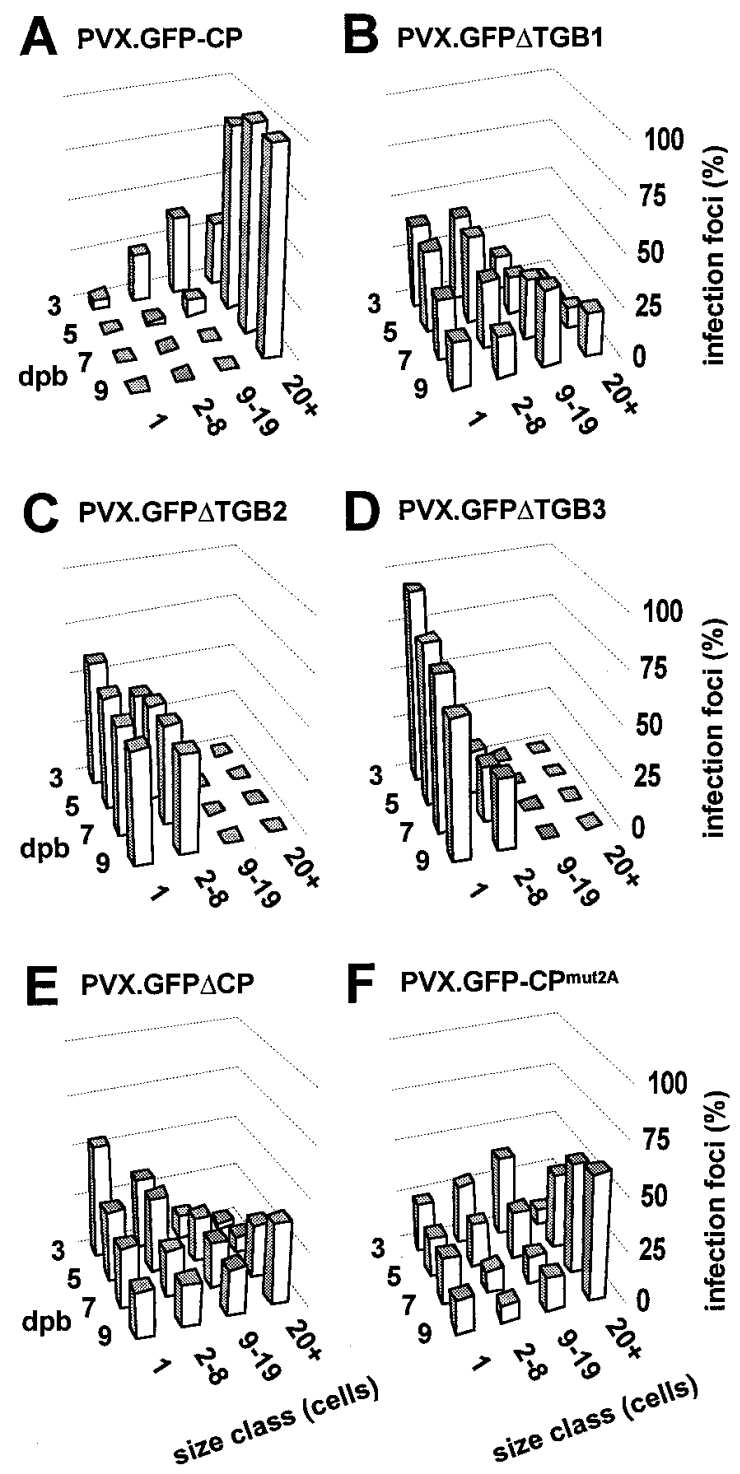

Fig. 4. Time course of rescue of cell-to-cell movement of wild-type and movement-deficient mutants of PVX.GFP-CP between mature epidermal cells of Nicotiana benthamiana following co-bombardment with the corresponding wild-type triple gene block (TGB) or coat protein $(\mathrm{CP})$ product expressed from a separate plasmid. Microprojectile bombardment was used to initiate virus infection. Extent of cell-to-cell movement was determined with aid of an epifluorescence microscope at 3, 5, 7 and 9 days post bombardment (dpb). Infection foci were distinguished into four classes: (i) restriction to initially bombarded cell; (ii) movement to adjacent cells resulting in foci of $2 \mathrm{ft}-8$ cells; (iii) movement beyond adjacent cells resulting in foci of 9-19 cells; and (iv) foci greater than 20 cells. Data were recorded and averaged from four independent experiments. Total impacts followed through time: PVX.GFP-CP $(n=499)$, PVX.GFP $\Delta$ TGB1 $(n=665)$, PVX.GFP $\Delta$ TGB2 $(n=211)$, PVX.GFP $\Delta$ TGB3 $(n=194), \operatorname{PVX.GFP~} \Delta \mathrm{CP}(n$ $=158)$ and PVX.GFP-CP ${ }^{\text {muLA }}(n=283)$. but could not be entirely eliminated. As virion accumulation could not be completely eliminated, we next explored whether the rate of potexvirus cell-to-cell movement could be enhanced without affecting virion accumulation. The factors that limit virus cell-to-cell movement include the requirements (i) to replicate within each cell and (ii) for synthesis of virusencoded products required for cell-to-cell movement (i.e., for the potexvirus, TGBp1, TGBp2, TGBp3, and the CP). Provision of these viral products, in trans, should circumvent one of the limitations on viral movement. If this is the case, WCIMVGFP should move more rapidly on a transgenic plant expressing all TGB proteins and the $\mathrm{CP}$, relative to infection on a control plant.

Transgenic plants expressing the entire TGB and CP (TGB plus $\mathrm{CP}$ ) were generated by crossing individual lines expressing TGB or CP proteins $\left(18.3_{2} \times 12.4_{2} \times \mathrm{S} 13\right.$; Lough et al. 1998). Apposing half-leaves of control or TGB plus CP expressing transgenic plants were inoculated with WClMVGFP and infection foci photographed at 5 dpi (Fig. 6). As predicted, the diameter of infection foci that developed on control plants infected with WCIMV-GFP was significantly smaller than that of those formed on the TGB plus CP expressing plants (cf. Figure 6A and B). This established that the rate of potexvirus cell-to-cell movement could be significantly increased by relieving the requirement to make TGBp1, TGBp2, TGBp3, and CP. Parallel inoculations were performed in which apposing half-leaves were inoculated with WCIMVGFP and with an engineered virus unable to express TGBp1, TGBp2, TGBp3, and CP (WCIMV-GFP $\Delta$ TGB1-3 $\Delta$ CP; Fig. $1 \mathrm{C})$. These experiments revealed that movement-deficient WCIMV-GFP $\Delta$ TGB1-3 $\Delta$ CP (Fig. 6A) was able to move at the same enhanced rate as WCIMV-GFP, when inoculated onto TGB plus CP expressing plants (Fig. 6B). The difference in size of infection foci was observed from the time of their first appearance ( 3 to $4 \mathrm{dpi}$ ). These same infection foci were subsequently analyzed to determine the level of virion accumulation. (While this phenomenon of enhanced cell-to-cell movement could be obtained in repeated experiments, we have not observed any enhancement with a variety of other movementdeficient mutants of WCIMV-GFP and plants expressing combinations other than the entire TGB plus CP.)

The impact of this enhanced rate of movement on virion accumulation was examined initially by leaf-dip analysis. Whereas WCIMV-GFP was easily detectable in foci of infection formed on TGB plus CP plants, the mutant WClMVGFP $\Delta$ TGB1-3 $\Delta$ CP could not be detected (Table 3 ). The more sensitive SSEM technique revealed high levels of virion accumulation of WClMV-GFP in TGB plus CP plants and an approximately 14-fold reduction in WCIMV-GFP $\Delta$ TGB1$3 \Delta \mathrm{CP}$ virion accumulation. To accommodate for assay insensitivity at high virion levels, a dilution series was performed. Based on results from these assays (Table 3), the relative difference in virus accumulation in equivalently sized infection foci for WCIMV-GFP and WCIMV-GFP $\Delta$ TGB1-3 $\Delta$ CP was not less than 220-fold. To allow comparison between these data and earlier SSEM studies, values were normalized to infection foci unit area (average WCIMV-GFP $\Delta$ TGB1-3 $\Delta$ CP and WClMV-GFP $\Delta \mathrm{CP}$ infection foci of 6.3 and $1.8 \mathrm{~mm}^{2}$, respectively). Based on this assay, we detected $43.6 \pm 11.5$ virions per $\mathrm{mm}^{2}$ for WCIMV-GFP $\Delta$ TGB1-3 $\Delta \mathrm{CP}$ on plants expressing $\mathrm{TGB}$ plus $\mathrm{CP}$ and $31.1 \pm 3.0$ virions per $\mathrm{mm}^{2}$ for 
WCIMV-GFP $\triangle \mathrm{CP}$ on plants of line $\mathrm{B}_{21}$ (represents an appropriate control for these studies). The equivalence of these values underscores that viral accumulation does not correlate with the enhanced rate of cell-to-cell movement, which was, in effect, doubled in the TGB plus CP background.

\section{DISCUSSION}

Co-translocation of specific viral products between cells.

Potexviruses are unique in that four separate viral protein products are required to affect cell-to-cell movement. The viral products and form in which they are transported between cells are addressed by this study. Elucidation of the underlying mechanism of viral movement will have an impact on our understanding of both intercellular trafficking pathways and the development of resistance strategies to potexviruses. The use of microprojectile bombardment and transient expression provided the opportunity to dissect the role of the TGB and CP in movement. Two patterns of rescue for movement-deficient PVX.GFP-CP mutants were observed, namely, into the adjoining cell(s), or through these cells and on into the surrounding tissues (both epidermal and mesophyll). Confinement of viral movement to the adjoining cells indicated that TGBp2 and TGBp3, as predicted (Lough et al. 1998), retained the capacity to rescue viral movement from the initially inoculated cell into the next cell layer. The inability of these proteins to be transported between cells may reflect their subcellular localization to membrane structures (Morozov et al. 1990). Thus, the role of TGBp2 and TGBp3 is either associated with the intracellular delivery of the viral RNA to the PD, possibly via a vesicular transport pathway, or at the level of interaction with the cellular machinery/docking sites at the PD. Consistent with this hypothesis, translational GFP fusions of TGBp3 are suggested to target TGBp2-containing vesicles to the periphery of the cell (Solovyev et al. 2000).

Movement-deficient PVX mutants unable to produce TGBp1 or CP were capable of moving well beyond the initially inoculated cell, demonstrating the co-translocation of these two proteins between cells with the viral RNA. This result, consistent with previous microinjection studies (Lough et al. 1998), confirmed that TGBp1 is the potexvirus MP. Support for this role in viral RNA transport between cells is provided by the observation that the TGBp1 of WCIMV competes with the endogenous product, KNOTTED-1, for the same intercellular transport pathway (W. J. Lucas and B. Xoconostle-Cázares, unpublished data). We would therefore predict that TGBp1 should immunolocalize to the PD and be associated with viral RNA at the periphery of spreading foci of infection. Support for this hypothesis is derived from the observation that the TGBp1 of the benyvirus Beet necrotic yellow vein virus was immunolocalized to the collar region of $\mathrm{PD}$ within infected cells (Erhardt et al. 1999).

Virion assembly is not sufficient for cell-to-cell movement.

Separable roles of the WCIMV CP in virion assembly and cell-to-cell movement were revealed following removal of five C-terminal amino acids, indicating a role for the $\mathrm{C}$ terminal domain of the $\mathrm{CP}$ in cell-to-cell movement. However, although movement was abolished, the capacity to form virions was retained. Transgenic plants expressing WCIMV CP efficiently rescued cell-to-cell movement of WCIMVGFP $\Delta$ C5. Hence, the mutant CP product, although competent

Table 2. Equivalent-sized foci are formed following inoculation of White clover mosaic virus (WClMV)-green fluorescent protein (GFP) and two movement-deficient coat protein (CP) mutants onto leaves of transgenic Nicotiana benthamiana expressing the WCIMV CP

\begin{tabular}{|c|c|c|c|}
\hline \multirow[b]{2}{*}{ Plant line } & \multirow[b]{2}{*}{ CP expression (\% total protein) ${ }^{\mathrm{a}}$} & \multicolumn{2}{|c|}{ Diameter of infection foci (mm) } \\
\hline & & WCIMV-GFP/ WCIMV-GFP $\Delta C 5^{b}$ & WCIMV-GFP / WCIMV-GFP $\Delta C^{b}$ \\
\hline $\mathrm{C}_{1}$ & 0 & $1.2 \pm 0.06 / 0$ & $1.2 \pm 0.05 / 0$ \\
\hline $\mathrm{B}_{21}$ & 0.01 & $1.1 \pm 0.05^{\mathrm{c}} / 0.7 \pm 0.04^{\mathrm{c}}$ & $1.5 \pm 0.08^{\mathrm{c}} / 1.5 \pm 0.04^{\mathrm{c}}$ \\
\hline S13 & 0.05 & $0.9 \pm 0.05^{c} / 0.9 \pm 0.05^{c}$ & $1.0 \pm 0.04^{c} / 1.1 \pm 0.04^{c}$ \\
\hline
\end{tabular}

${ }^{a}$ The level of WCIMV CP expression was determined by Western blot (immunoblot) analysis and is expressed as percent total soluble protein.

${ }^{\mathrm{b}}$ Complementation was determined by inoculating apposing half-leaves with either WCIMV-GFP and WCIMV-GFP $\Delta$ C5 or with WCIMV-GFP and WCIMV-GFP $\Delta$ CP. Infection foci were photographed at 6 days post inoculation. Experimental data analyzed with residual maximum likelihood (REML), Fisher least significant differences (LSDs) calculated with an $\alpha=0.05$ threshold. The mean foci $(\mathrm{mm}) /$ half-leaf, $x \pm s e(x)$, where $s e(x)=$ $s d(x) / \sqrt{ } n,(n=27-90)$ is shown.

${ }^{\mathrm{c}}$ There was no significant difference in the diameter of infection foci formed between the two different viruses on apposing halves of the same leaf (LSD $=0.44$, the probability of rejection of any two sample means was derived with $\alpha=0.05$ in error bar calculation).

Table 3. Analysis of virion accumulation in foci of infection formed following rescue of movement-deficient mutants of White clover mosaic virus (WCIMV)-green fluorescent protein (GFP) by transgenic plants expressing the WCIMV CP or the entire triple gene block (TGB) plus CP

\begin{tabular}{|c|c|c|c|c|}
\hline \multirow[b]{2}{*}{ Virus } & \multicolumn{4}{|c|}{ Virions per grid square ${ }^{a}$ (leaf-dip / serum-specific electron microscopy [SSEM]) } \\
\hline & $\mathbf{C}_{1}$ & $\mathbf{B}_{21}$ & S13 & TGB plus CP \\
\hline WCIMV-GFP & $274 \pm 88 / 6,033 \pm 1,250$ & $172 \pm 53 / 3,502 \pm 359$ & $60 \pm 48 / 4,154 \pm 506$ & $221 \pm 65 / 3,800 \pm 726(1,549 \pm 262)^{b}$ \\
\hline WCIMV-GFP $\triangle \mathrm{CP}$ & $0 / 0$ & $0.6 \pm 0.6 / 55 \pm 5.3$ & $0 / 11.8 \pm 4.3$ & \\
\hline WCIMV-GFP $\Delta$ C5 & $0 / 1.6 \pm 0.8$ & $6.3 \pm 2.7 / 1,292 \pm 309$ & $38 \pm 25 / 2,618 \pm 724$ & \\
\hline WCIMV-GFP $\Delta$ TGB1-3 $\Delta \mathrm{CP}$ & & & & $0 / 272 \pm 72(7 \pm 3.2)^{\mathrm{b}}$ \\
\hline Mock inoculated & $0 / 0$ & $0 / 0$ & $0 / 0$ & $0 / 0$ \\
\hline
\end{tabular}



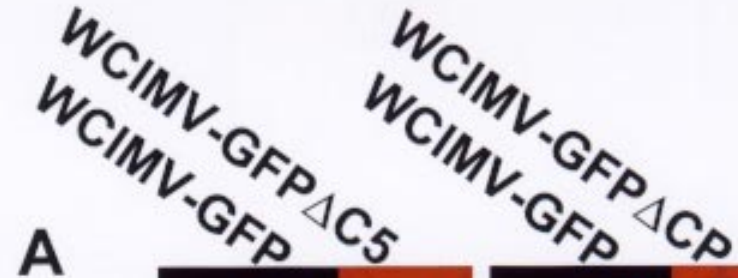

$\mathrm{C}_{1}$
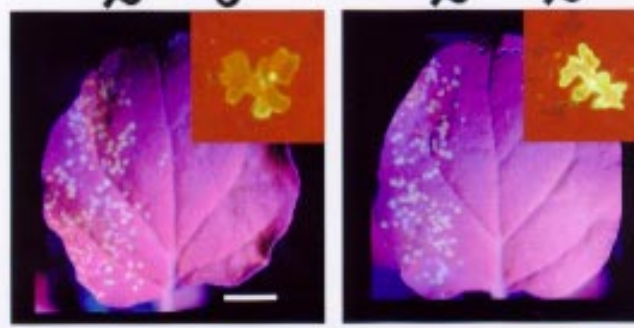

$B_{21}$
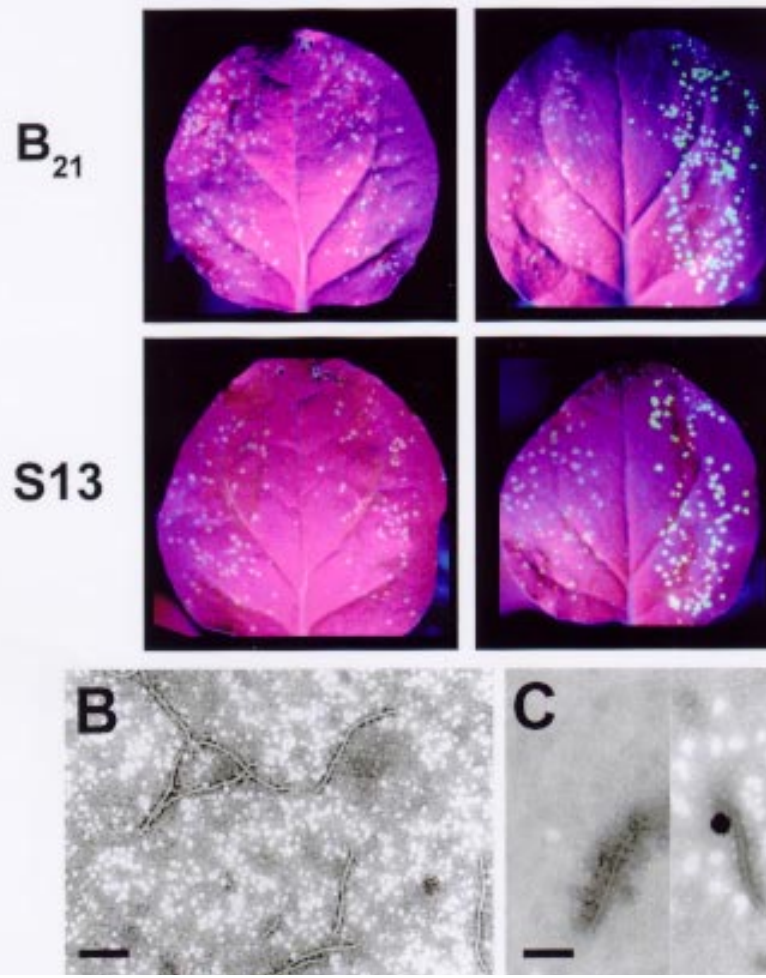

Fig. 5. Complementation of the coat protein $(\mathrm{CP})$ mutants of the potexvirus White clover mosaic virus (WCIMV) by transgenic Nicotiana benthamiana plants expressing the WCIMV CP. Viral inoculations were performed with apposed half-leaves (infection foci formed by WCIMV-green fluorescence protein (GFP) on left side of leaves and WClMV-GFP $\Delta \mathrm{C} 5$ or WCIMV$\mathrm{GFP} \Delta \mathrm{CP}$ on right side of leaves). Spreading infection foci were visualized by long-wave-length UV illumination; single fluorescent cells were visualized with a fluorescence microscope. Differences in intensity of the GFP reporter expressed by WCIMV-GFP $\Delta \mathrm{C} 5$ or WCIMV-GFP $\Delta \mathrm{CP}$ reflect differences in promoter strength driving subgenomic RNA synthesis. Scale bar $=1 \mathrm{~cm}$. A, Susceptibility of control $\mathrm{C}_{1}$ leaves to WCIMV-GFP and restriction of WCIMV-GFP $\triangle \mathrm{C} 5$ and WCIMV-GFP $\triangle \mathrm{CP}$ to initially inoculated cell (inset). Both WCIMV-GFP $\Delta \mathrm{C} 5$ and WCIMV-GFP $\triangle \mathrm{CP}$ were rescued for cell-to-cell movement by transgenic plants of lines $\mathrm{B}_{21}$ and $\mathrm{S} 13$ expressing the WCIMV CP. Infection foci formed on transgenic plants for each of the viral mutants and the control WCIMV-GFP are equivalent in size. B and C, Electron micrograph of (B) WCIMV-GFP, and (C) WCIMVGFP $\Delta$ C5 virions captured by serum-specific electron microscopy (SSEM) from infection foci formed on control $\mathrm{C}_{1}$ plants. The formation of virions by WCIMV-GFP $\Delta \mathrm{C} 5$ on control $\mathrm{C}_{1}$ tissue indicates that the mutant $\mathrm{CP}$ retains the capacity to assemble virions. for virion assembly, did not interfere, in a dominant negative manner, with any additional required interactions to affect viral movement. At this point, it is unclear whether the $\mathrm{CP} C$ terminus is required to interact with the viral RNA, TGBp1, or

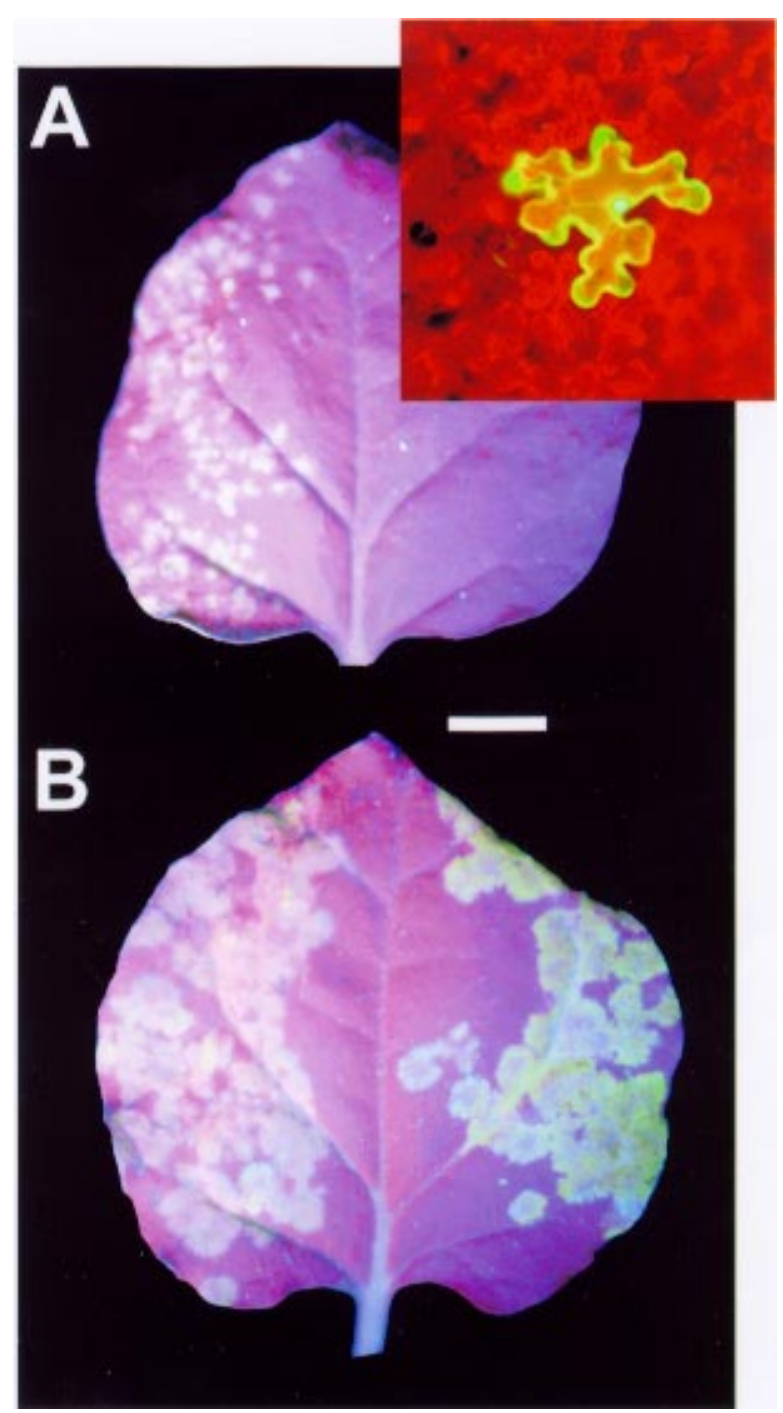

Fig. 6. Enhanced rate of cell-to-cell movement of White clover mosaic virus (WCIMV)-green fluorescence protein (GFP) and the movementdeficient mutant WCIMV-GFP $\Delta$ TGB1-3 $\Delta$ CP following inoculation of transgenic Nicotiana benthamiana plants expressing the WClMV triple gene block (TGB) plus coat protein (CP). Viral inoculations were performed with apposed half-leaves (foci formed by WCIMV-GFP on left side of leaves and WCIMV-GFP $\Delta$ TGB1-3 $\Delta \mathrm{CP}$ on right side of leaves). Infection foci were visualized by long-wave-length UV illumination; single fluorescent cells, with a fluorescence microscope. Scale bar $=1 \mathrm{~cm}$. A, Susceptibility of control $\mathrm{C}_{1}$ leaves to WCIMV-GFP and restriction of WClMV-GFP $\Delta$ TGB1-3 $\Delta$ CP to initially inoculated cell (inset). B, Cell-tocell movement of WCIMV-GFP $\Delta$ TGB1-3 $\Delta$ CP was rescued by transgenic plants expressing TGB plus CP. Both WCIMV-GFP and WCIMVGFP $\Delta$ TGB $1-3 \Delta C P$ formed equivalent sized infection foci and each virus exhibited an enhanced rate of cell-to-cell movement on transgenic plants expressing TGB plus CP. Mean foci $(\mathrm{mm}) /$ half-leaf \pm SD $(n=146-$ 163) was determined at 6 days post inoculation (dpi). WCIMV-GFP formed $1.2 \pm 0.03 \mathrm{~mm}$ foci of infection on control plants and $2.6 \pm 0.05$ $\mathrm{mm}$ foci on transgenic plants expressing the WCIMV TGB and CP. Single-cell restricted foci of infection were observed by WClMVGFP $\Delta$ TGB $1-3 \Delta \mathrm{CP}$ on control plants and $2.8 \pm 0.08 \mathrm{~mm}$ foci on transgenic plants expressing the WCIMV TGB and CP. 
cellular factors, to affect cell-to-cell movement. In view of the inaccessibility of the $\mathrm{C}$ terminus of the $\mathrm{CP}$ in virions to tritium bombardment labeling (Baratova et al. 1992) and the dispensability of exposed N-terminal amino acids for movement (Chapman et al. 1992), it is difficult to reconcile the role played in cell-to-cell movement by the exposed regions of the $\mathrm{CP}$ in an assembled virion. In any case, we have demonstrated that an assembly-competent form of the $\mathrm{CP}$ will not support cell-to-cell virus movement. The movement deficiency of mutant WCIMV-GFP $\Delta$ C5 can more readily be interpreted in terms of an inability of the truncated $\mathrm{CP}$ to fulfill required interactions of the CP as part of a non-virion RNP.

\section{The rate-limiting factor of potexvirus movement is not virion accumulation.}

Movement-deficient mutants, WCIMV-GFP $\Delta \mathrm{CP}$, WCIMVGFP $\Delta$ C5, and WCIMV-GFP $\Delta$ TGB1-3 $\Delta C$, were all efficiently rescued for cell-to-cell movement when inoculated onto the appropriate transgenic plant lines. However, there were substantial differences in levels of virion formation between mutants WCIMV-GFP $\Delta \mathrm{CP}$ or WCIMV-GFP $\Delta$ TGB1$3 \Delta \mathrm{CP}$ and mutant WClMV-GFP $\Delta \mathrm{C} 5$. The higher level of virion accumulation by mutant WCIMV-GFP $\Delta \mathrm{C} 5$ undoubtedly reflects the availability of both the transgene-derived $\mathrm{CP}$ and the encapsidation-competent mutant $\mathrm{CP}$. By contrast, the transgene $\mathrm{CP}$ concentration in lines $\mathrm{B}_{21}$ and $\mathrm{S} 13$ (or the derivative line expressing the entire TGB plus $\mathrm{CP}$ ) is clearly sufficient to permit only a limited amount of virion accumulation by mutants WCIMV-GFP $\Delta \mathrm{CP}$ and WCIMV-GFP $\Delta$ TGB1$3 \Delta \mathrm{CP}$. Despite the sub-optimal level, and by implication, suboptimal rate of virion accumulation of these mutants, we could not measure any detectable reduction in size of infection foci, or in their rate of development in CP-expressing lines. Further, the enhanced rate of cell-to-cell movement in leaves expressing the entire TGB and $\mathrm{CP}$ was also unaffected by the decreased efficiency of virion formation by mutant WCIMVGFP $\Delta$ TGB1-3 $\Delta$ CP. The rate-limiting step of cell-to-cell movement is, therefore, not imposed by virion accumulation, but rather is related to the availability of TGB and $\mathrm{CP}$ products in the infected cell.

Two viable models remain for potexvirus cell-to-cell movement. Clearly, the transport of virions, even when present at low levels, may be sufficient to mediate efficient cellto-cell spread of the virus. If this mechanism were valid, the pathway would necessarily have to act at high affinity, to recognize and affect both intracellular and intercellular transport of virus particles. The validity of this model was tested by engineering experimental conditions in which we achieved a doubling of the rate of WCIMV cell-to-cell movement. Importantly, under these conditions, the level of virion accumulation remained unaffected. Thus, virions are not a factor limiting viral cell-to-cell movement. Data presented in this study remain consistent with the movement between cells of an RNP, as doubling the rate of cell-to-cell movement was directly correlated with the expression of TGB plus CP. In our model, membrane-associated products TGBp2 and TGBp3 are proposed to function, intracellularly, in the delivery to the PD of an RNP complex comprising TGBp1, the $\mathrm{CP}$, and viral RNA.

A number of studies have identified potexvirus virions embedded in the PD and, as such, have been used as evidence to implicate virions in the movement process per se (Robards and Lucas 1990; Rouleau et al. 1995; Santa Cruz et al. 1998; Shalla and Sheppard 1972; P. Sutherland and R. L. S. Forster, unpublished data). The question that needs to be resolved is whether the presence of these particles represents a "snapshot" of the active process of potexvirus cell-to-cell movement, or is the result of secondary, unrelated, events, e.g., de novo synthesis of virions in the cavity of the PD. Both the size of PVX particles (12.6 nm diameter; Santa Cruz et al. 1996) and their flexuous nature are compatible with cell-tocell movement of virions via the PD. From these considerations alone, one would predict that an increase in virion diameter should have a negative impact on the capacity for cellto-cell movement. However, when the diameter of PVX particles was more than doubled, as was the case for the modified virus, PVX-GFP (29.7 nm; Santa Cruz et al. 1996), the ability to move cell to cell was retained. In this case, viral cell-to-cell movement may well represent the involvement of the RNP rather than virions. Taken together, evidence presented here based on WCIMV and PVX supports viral movement between cells in the form of an RNP. It remains to be established whether this transported form is utilized in different hosts or indeed during transport between different cell types of the same host. It will be of particular interest, in this regard, to focus on the processes of vascular loading and translocation of potexviruses.

\section{MATERIALS AND METHODS}

Cloning.

The viral cDNA sequence of the potexvirus PVX (strain UK3) from the plasmid pTXS.GFP-CP (Santa Cruz et al. 1996) was placed under the transcriptional control of the $35 \mathrm{~S}$ promoter, creating pCaX.GFP-CP (Oparka et al. 1999). Plasmids pCaX.GFP-CP $\Delta \mathrm{CP}$ and $\mathrm{pCaX}$.GFP-CP ${ }^{\text {mut2A }}$ were created by replacement of the BamHI-SpeI restriction endonuclease fragment of pCaX.GFP-CP with the equivalent fragments from pTXS.GFP- $\triangle C P$ (Baulcombe et al. 1995) and pTXS.GFP-CP ${ }^{\text {mut2A }}$ (Santa Cruz et al. 1996). Frameshift mutations in the TGB1 ORF at ApaI (position 4945) and the TGB2 ORF at $\mathrm{XbaI}$ (position 5249) restriction endonuclease sites resulted in plasmids pCaX.GFP-CP $\Delta$ TGB1 and pCaX.GFP-CP $\triangle \mathrm{TGB} 2$, respectively. The initiation codon of PVX.GFP-CP TGB3 was mutated from AUG to ACG by a PCR-based mutagenesis procedure, resulting in pCaX.GFP$\mathrm{CP} \Delta \mathrm{TGB} 3$. Infectious PVX plasmids are referred to by replacing the $\mathrm{pCaX}$ prefix with $\mathrm{p} 35 \mathrm{~S}-\mathrm{PVX}$. Transient expression vectors p35S-TGB1, p35S-TGB2, p35S-TGB3, and p35S-CP were created by directionally cloning the appropriate ORFs of PVX as PCR products flanked with $\mathrm{NcoI}$ and $\mathrm{SacI}$ restriction endonuclease sites into the corresponding sites of the transient expression vector pRTL2 (Restrepo et al. 1990).

Infectious clones of WClMV, incorporating an SP6 RNA polymerase promoter to generate in vitro infectious RNA transcripts, are based on pWClMV-6 (Beck et al. 1990). The plasmid pWCIMV-GFP $\Delta$ CP was constructed by modification of pWClMV-6 by site-directed mutagenesis (Morph kit; 5 prime 3 prime, Boulder, CO) to incorporate an SphI endonuclease restriction site at position 5199 and to mutate the CP initiation codon from AUG to AGG. The GFP ORF was amplified by PCR with pTXS.GFP-CP as template and ligated 
into the engineered $S p h \mathrm{I}$ restriction endonuclease site, resulting in a frameshift out of the CP reading frame with a stop codon occurring six nucleotides downstream of the GFP coding sequence. The plasmid pWCIMV-GFP was constructed by ligating an $A f l \mathrm{II} / \mathrm{Sall}$-digested PCR fragment (representing the $\mathrm{CP}$ subgenomic promoter, the CP coding sequence, $3^{\prime}$ untranslated region and 74 adenosine residues; nucleotides 5100 to $5846+74 \mathrm{As}$ ) into $A f l \mathrm{II} / \mathrm{Sall}$-digested pWClMV-GFP $\Delta \mathrm{CP}$. The plasmid pWCIMV-GFP $\Delta \mathrm{C} 5$ was constructed by insertion of a termination of translation codon (at position 5776), by site directed mutagenesis (Morph kit; 5 prime 3 prime, Boulder, $\mathrm{CO}$ ), resulting in the truncation of the $\mathrm{CP}$ product by five amino acids. The plasmid pWCIMV $\Delta$ TGB1-3 $\Delta$ CP was created by deleting WCIMV bases 4022 to 5101 (NotI-BstBI restriction fragment) and 5195 to 5696 (XhoI-NruI restriction fragment) from pWCIMV-GFP. In this instance, bases 5697 to 5846 , including the $3^{\prime}$ untranslated sequences, remained intact. Site-directed mutagenesis (insertion of a NotI site at position 4022) of pWClMV-GFP facilitated deletion of the Not IBstBI fragment.

All constructs were sequenced to confirm the nature of engineered mutations. Nucleotide and amino acid sequences were analyzed with UWGCG version 10.0-UNIX programs (Devereux et al. 1984). Infections established with the infectious PVX plasmids above are referred to without the prefix p35S-. Infections established with the infectious WCIMV plasmids are referred to in the absence of the plasmid (p) prefix. Numbering of the nucleotide sequence of PVX and WCIMV RNA is according to Huisman et al. (1988) and Beck et al. (1990), respectively.

\section{Microprojectile bombardment.}

The upper (adaxial) epidermis of fully expanded leaves of $N$. benthamiana or $N$. tabacum was bombarded with gold particles coated with various DNA preparations with a Biolistic PDS 1000/He System (BioRad, Hercules, CA) at a pressure of $900 \mathrm{lb} / \mathrm{in}^{2}$. Co-bombardment with TGBp1 or CP protein preparations was performed following precipitation of TGBp1 or $\mathrm{CP}$ onto the gold particles by acetone with a procedure described by Xoconostle-Cázares et al. (1999). Briefly, $5 \mu \mathrm{g}$ of protein was mixed with a 5- $\mu$ l aliquot of gold particles (stock of gold particles at $20 \mathrm{mg} / \mathrm{ml}$ in ethanol). Ice cold acetone (3 volumes) was added to the mixture and allowed to incubate at $4^{\circ} \mathrm{C}$ for $10 \mathrm{~min}$. The particles were washed once with $70 \%$ ethanol and twice with $95 \%$ ethanol. The gold particles were resuspended in $30 \mu \mathrm{l}$ of ethanol, $5 \mu \mathrm{l}$ of which was used for each bombardment. After bombardment, the leaves were kept in petri dishes on damp filter paper at $20^{\circ} \mathrm{C}$ in a growth room with a 16-h day / 8-h night cycle.

\section{Transgenic plants.}

The entire WCIMV TGB coding sequence (with $\beta$ glucuronidase [GUS] inserted as a translational fusion at position 4833 within the TGB2 ORF) was subcloned into the binary vector pART27 (Gleave 1992) and introduced into $N$. benthamiana by Agrobacterium tumefaciens-mediated leaf disk transformation (Horsch et al. 1985). A total of 18 plant lines were regenerated and designated $18.3_{1-18}$. Seed from selected transformed lines was allowed to self-pollinate and homozygous seed from the $\mathrm{T}_{2}-\mathrm{T}_{3}$ progeny were used throughout this study. Expression of TGBp1 in progeny of selected lines was confirmed by functional rescue of a movementdeficient WCIMV mutant unable to express TGBp1. A total of three independent transformants $\left(\mathrm{B}_{11,21,24}\right)$ were regenerated from a construct designed to express the WCIMV CP ORF. Plants expressing the WCIMV CP (line S13) or the TGB2 and TGB3 ORFs (line 12.4 ) have been previously described (Lough et al. 1998). Plants expressing TGB plus CP were generated by crossing homozygous $\mathrm{T}_{3}-\mathrm{T}_{5}$ progeny of lines $18.3_{2}$ (expressing TGBp1) and $12.4_{2}$ (expressing TGBp2 and TGBp3). The progeny of this cross were crossed with homozygous $\mathrm{T}_{5}$ progeny of plant line $\mathrm{S} 13$ (a CP-expressing plant line). Progeny expressing the TGB plus $\mathrm{CP}$ were identified following rescue of cell-to-cell movement after inoculation with WCIMV-GFP $\Delta$ TGB1-3 $\Delta$ CP by a detached leaf assay.

\section{Inoculation of WCIMV transcripts.}

Transcripts were produced in vitro with SP6 RNA polymerase and were mechanically inoculated onto plants as previously described (Beck et al. 1990). Plants were maintained in a containment greenhouse and GFP expression was detected with a hand-held, long-wave-length, ultraviolet lamp (UVP, Upland, CA).

\section{Epifluorescence microscopy and confocal laser scanning imaging.}

Movement of PVX.GFP-CP within the epidermis and mesophyll of $N$. benthamiana leaves was observed with an Olympus Vanox epifluorescence microscope equipped with a filter set consisting of a blue excitation filter (420 to $490 \mathrm{~nm}$ ), a dichroic mirror $(510 \mathrm{~nm})$, and a green barrier filter (520 to 560 nm) (Olympus, Tokyo) or a Leica (model TCS-4D; Leica, Heidelberg, Germany) upright confocal laser scanning microscope (CLSM). All permanent images were obtained with the Leica CLSM, with a long-working-distance $16 \times$ multimedia objective or a $25 \times$ oil immersion lens. A low intensity laser $(75 \mathrm{~mW}$ RYB Krypton/Argon laser; Omnichrome 643-75RYB) was used to image the spatial distribution of GFP. Two-channel recordings were made with the following filter sets: (i) GFP, $488 \mathrm{~nm}$ excitation, $525 \mathrm{~nm}$ emission (BPFITC filter); (ii) FM 1-43, $488 \mathrm{~nm}$ excitation, >590 nm emission (OG590 filter). The cellular outline of leaf epidermal cells was revealed with the lipophilic dye FM 1-43 (catalog no. T-3163; Molecular Probes, Eugene OR). Briefly, FM 1-43 was resuspended at $1 \mathrm{mg} / \mathrm{ml}$ in methanol. A working solution was made from this by diluting the stock 1,000-fold into $10 \%$ methanol. Upon completion of image capture for GFP fluorescence associated with PVX.GFP-CP, the microscope stage was lowered and a 30- $\mu$ drop applied close to the area of interest and allowed to stain for 5 to $10 \mathrm{~min}$. The stage was raised, the cellular outline re-focused, and the image captured with the settings described above. Image analysis, display (adjustments in contrast, brightness, etc.), and preparation for plates were all performed with Adobe Photoshop (Adobe Systems, Mountain View, CA).

\section{Electron microscopy.}

Analysis of extracts from inoculated leaves, negatively stained with $1 \%$ phosphotungstate (leaf-dips), was performed essentially as described by Hitchborn and Hills (1965). SSEM was performed with WClMV CP-specific antisera as previously described (Lough et al. 1998). Ten foci were excised from each leaf with a cork borer, crushed in buffer. and ex- 
amined by leaf-dip or SSEM. Virion numbers were determined as the mean \pm SD of virions observed in 10 random views per grid square (10 grid squares were examined per grid).

\section{ACKNOWLEDGMENTS}

We thank Simon Santa Cruz for PVX.GFP-CP constructs and helpful discussions throughout the period of this study. We thank Colin Green and Hilary Holloway for assistance with confocal microscopy at the University of Auckland Biomedical Imaging Centre, Department of Anatomy, School of Medicine. We are grateful to Julie Nicholls for maintenance of plants in the greenhouse, Sharlene Cookson and Matt Pascoe for assistance with the preparation of figures, and Marcus Davy for assistance with statistical analyses. We thank Ezequiel Balmori for access to WCIMV infectious clones and Petra Boevink for pPVX.GFPATGB3 (8KSS). We acknowledge technical assistance from Davin Voot at the early stages of this study. We thank Beatriz Xoconostle-Cázares for helpful discussions on protein/DNA co-bombardment and on confocal microscopy. This work was supported by grants from the Foundation of Research Science and Technology (FoRST \#CO6816, to R. L. S. F.) and National Science Foundation (IBN 99-00539, to W. J. L.).

\section{LITERATURE CITED}

Agranovsky, A. A., Folimonov, A. S., Folimonova, S. Y., Morozov, S. Y., Schiemann, J., Lesemann, D., and Atabekov, J. G. 1998. Beet yellows closterovirus HSP70-like protein mediates the cell-to-cell movement of a potexvirus transport-deficient mutant and a hordeivirus-based chimeric virus. J. Gen. Virol. 79:889-895.

Baratova, L. A., Grebenshchikov, N. I., Dobrov, E. N., Gedrovich, A. V., Kashirin, I. A., Shishkov, A. V., Efimov, A. V., Jarvekulg, L., Radavsky, Y. L., and Saarma, M. 1992. The organization of potato virus $\mathrm{X}$ coat proteins in virus particles studied by tritium planigraphy and model building. Virology 188:175-180.

Baulcombe, D. C., Chapman, S., and Santa Cruz, S. 1995. Jellyfish green fluorescent protein as a reporter for virus infections. Plant J. 7:10451053.

Beck, D. L., Forster, R. L. S., Bevan, M. W., Boxen, K. A., and Lowe, S. C. 1990. Infectious transcripts and nucleotide sequence of cloned cDNA of the potexvirus white clover mosaic virus. Virology 177:152158.

Beck, D. L., Guilford, P. J., Voot, D. M., Andersen, M. T., and Forster, R. L. S. 1991. Triple gene block proteins of white clover mosaic potexvirus are required for transport. Virology 183:695-702.

Carrington, J. C., Kasschau, K. D., Mahajan, S. K., and Schaad, M. C. 1996. Cell-to-cell and long-distance transport of viruses in plants. Plant Cell 8:1669-1681.

Chapman, S., Hills, G., Watts, J., and Baulcombe, D. 1992. Mutational analysis of the coat protein gene of potato virus X: Effects on virion morphology and viral pathogenicity. Virology 191:223-230.

Dawson, W. O., Bubrick, P., and Grantham, G. L. 1988. Modifications of the tobacco mosaic virus coat protein gene affecting replication, movement, and symptomatology. Phytopathology 78:783-789.

Devereux, J., Haeberli, P., and Smithies, O. 1984. A comprehensive set of sequence analysis programs for the VAX. Nucleic Acids Res. 12: 387-395.

Erhardt, M., Stussi-Garaud, C., Guilley, H., Richards, K. E., Jonard, G., and Bouzoubaa, S. 1999. The first triple gene block protein of peanut clump virus localizes to the plasmodesmata during virus infection. Virology 264:220-229.

Forster, R. L. S., Beck, D. L., Guilford, P. J., Voot, D. M., van Dolleweerd, C. J., and Andersen, M. T. 1992. The coat protein of white clover mosaic potexvirus has a role in facilitating cell-to-cell transport in plants. Virology 191:480-484.

Fujiwara, T., Giesman-Cookmeyer, D., Ding, B., Lommel, S. A., and Lucas, W. J. 1993. Cell-to-cell trafficking of macromolecules through plasmodesmata potentiated by the red clover necrotic mosaic virus movement protein. Plant Cell 5:1783-1794.

Ghoshroy, S., Lartey, R., Sheng, J., and Citovsky, V. 1997. Transport of proteins and nucleic acids through plasmodesmata. Annu. Rev. Plant Physiol. Plant Mol. Biol. 48:27-50.
Gleave, A. P. 1992. A versatile binary vector system with a T-DNA organisational structure conducive to efficient integration of cloned DNA into the plant genome. Plant Mol. Biol. 20:1203-1207.

Hamilton, W. D. O., and Baulcombe, D. C. 1989. Infectious RNA produced by in vitro transcription of a full-length tobacco rattle virus RNA-1 cDNA. J. Gen. Virol. 70:963-968.

Heinlein, M., Epel, B.L., Padgett, H.S., and Beachy, R. N. 1995. Interaction of tobamovirus movement proteins with the plant cytoskeleton. Science 270:1983-1985.

Hitchborn, J. H., and Hills, G. J. 1965. The use of negative staining in the electron microscopic examination of plant viruses in crude extracts. Virology 27:528-540.

Horsch, R. B., Fry, J. E., Hoffmann, N. L., Eichholtz, D., Rogers, S. G., and Fraley, R. T. 1985. A simple and general method for transferring genes into plants. Science 227:1229-1231.

Huisman, M. J., Linthorst, H. J. M., Bol, J. F., and Cornelissen, B. J. C. 1988. The complete nucleotide sequence of potato virus $\mathrm{X}$ and its homologies at the amino acid level with various plus-stranded RNA viruses. J. Gen. Virol. 69:1789-1798.

Hull, R. 1989. The movement of viruses in plants. Annu. Rev. Phytopathol. 27:213-240

Itaya, A., Hickman, H., Bao, Y., Nelson, R., and Ding, B. 1997. Cell-tocell trafficking of cucumber mosaic virus movement protein:green fluorescent protein fusion produced by biolistic gene bombardment in tobacco. Plant J. 12:1223-1230.

Kasteel, D. T. J., van der Wel, N. N., Jansen, K. A. J., Goldbach, R. W., and van Lent, J. W. M. 1997. Tubule-forming capacity of the movement proteins of alfalfa mosaic virus and brome mosaic virus. J. Gen. Virol. 78:2089-2093.

Kragler, F., Monzer, J., Shash, K., Xoconostle-Cázares, B., and Lucas, W. J. 1998. Cell-to-cell transport of proteins: Requirement for unfolding and characterization of binding to a putative plasmodesmal receptor. Plant J. 15:367-381.

Lazarowitz, S. G., and Beachy, R. N. 1999. Viral movement proteins as probes for intracellular and intercellular trafficking in plants. Plant Cell 11:535-548.

Lough, T. J., Shash, K., Xoconostle-Cázares, B., Hofstra, K. R., Beck, D. L., Balmori, E., Forster, R. L. S., and Lucas, W. J. 1998. Molecular dissection of the mechanism by which potexvirus triple gene block proteins mediate cell-to-cell transport of infectious RNA. Mol. PlantMicrobe Interact. 11:801-814.

Lucas, W. J., and Gilbertson, R. L. 1994. Plasmodesmata in relation to viral movement within leaf tissues. Annu. Rev. Phytopathol. 32:387-411.

Maule, A. J. 1991. Virus movement in infected plants. Crit. Rev. Plant Sci. 9:457-473.

Morozov, S. Y., Fedorkin, O. N., Juttner, G., Schiemann, J., Baulcombe, D. C., and Atabekov, J. G. 1997. Complementation of a potato virus X mutant mediated by bombardment of plant tissues with cloned viral movement protein genes. J. Gen. Virol. 78:2077-2083.

Morozov, S. Y., Miroshnichenko, N. A., Zelenina, D. A., Fedorkin, O. N., Solovijev, A. G., Lukasheva, L. I., and Atabekov, J. C. 1990. Expression of RNA transcripts of potato virus $\mathrm{X}$ full-length and subgenomic cDNAs. Biochimie 72:677-684.

Noueiry, A. O., Lucas, W. J., and Gilbertson, R. L. 1994. Two proteins of a plant DNA virus coordinate nuclear and plasmodesmal transport. Cell 76:925-932.

Oparka, K. J., Roberts, A. G., Boevink, P., Santa Cruz, S., Roberts, I., Pradel, K. S., Imlau, A., Kotlizky, G., Sauer, N., and Epel, B. 1999. Simple, but not branched, plasmodesmata allow the nonspecific trafficking of proteins in developing tobacco leaves. Cell 97:743-54.

Oparka, K. J., Roberts, A. G., Roberts, I. M., Prior, D. A. M., and Santa Cruz, S. 1996. Viral coat protein is targeted to, but does not gate, plasmodesmata during cell-to-cell movement of potato virus X. Plant J. 10: 805-813.

Petty, I. T. D., and Jackson, A. O. 1989. Mutational analysis of barley stripe mosaic virus RNA $\beta$. Virology 179:712-718.

Quillet, L., Guilley, H., Jonard, G., and Richards, K. 1989. In vitro synthesis of biologically active beet necrotic yellow vein virus RNA. Virology 172:293-301.

Restrepo, M. A., Freed, D. D., and Carrington, J. C. 1990. Nuclear transport of plant potyviral proteins. Plant Cell 2:987-998.

Ritzenthaler, C., Schmit, A.-C., Michler, P., Stussi-Garaud, C., and Pinck, L. 1995. Grapevine fanleaf nepovirus P38 putative movement protein is located on tubules in vivo. Mol. Plant-Microbe. Interact. 8: 
379-387.

Rojas, M. R., Zerbini, F. M., Allison, R. F., Gilbertson, R. L., and Lucas, W. J. 1997. Capsid protein and helper component-proteinase function as potyvirus cell-to-cell movement proteins. Virology 237:283-295.

Robards, A. W., and Lucas, W. J. 1990. Plasmodesmata. Annu. Rev. Plant Physiol. Plant Mol. Biol. 41:369-419.

Rouleau, M., Smith, R. J., Bancroft, J. B., and Mackie, G. A. 1995. Subcellular immunolocalization of the coat protein of two potexviruses in infected Chenopodium quinoa. Virology 214:314-318.

Saito, T., Yamanaka, K., and Okada, Y. 1990. Long-distance movement and virion assembly of tobacco mosaic virus mutants. Virology 176: 329-336.

Santa Cruz, S., Chapman, S., Roberts, A. G., Roberts, I. M., Prior, D. A. M., and Oparka, K. J. 1996. Assembly and movement of a plant virus carrying a green fluorescent protein overcoat. Proc. Natl. Acad. Sci. USA 93:6286-6290.

Santa Cruz, S., Roberts, A. G., Prior, D. A., Chapman, S., and Oparka, K. J. 1998. Cell-to-cell and phloem-mediated transport of potato virus X: The role of virions. Plant Cell 10:495-510.

Scholthof, H. B., Morris, T. J., and Jackson, A. O. 1993. The capsid protein gene of tomato bushy stunt virus is dispensable for systemic movement and can be replaced for localized expression of foreign genes. Mol. Plant-Microbe Interact. 6:309-322.

Shalla, T. A., and Shepard, J. F. 1972. The structure and antigenic analysis of amorphous inclusion bodies induced by potato virus X. Virology 49:654-677.

Shukla, D. D., and Gough, K. H. 1979. The use of protein A, from Staphylococcus aureus, in immune electron microscopy for detecting plant virus particles. J. Gen. Virol. 45:533-536.

Solovyev, A. G., Stroganova, T. A., Zamyatnin, A. A., Fedorkin, O. N., Schiemann, J., and Morozov, S. Y. 2000. Subcellular sorting of small membrane-associated triple gene block proteins: TGBp3-assisted tar- geting of TGBp2. Virology 269:113-127.

Spillane, C., Verchot, J., Kavanagh, T. A., and Baulcombe, D. C. 1997. Concurrent suppression of virus replication and rescue of movementdeficient virus in transgenic plants expressing the coat protein of potato virus X. Virology 236:76-84.

Storms, M. M. H., Kormelink, R., Peters, D., van Lent, J. W. M., and Goldbach, R. W. 1995. The nonstructural NSm protein of tomato spotted wilt virus induces tubular structures in plant and insect cells. Virology 214:485-493.

Storms, M. M. H., van der Schoot, C., Prins, M., Kormelink, R. van Lent, J. W. M., and Goldbach, R. W. 1998. A comparison of two methods of microinjection for assessing altered plasmodesmal gating in tissues expressing viral movement proteins. Plant J. 13:131-140.

van Lent, J., Wellink, J., and Goldbach, R. 1990. Evidence for the involvement of the $58 \mathrm{~K}$ and $48 \mathrm{~K}$ proteins in the intercellular movement of cowpea mosaic virus. J. Gen. Virol. 71:219-223.

Van Regenmortel M. H. V., Fauquet C. M., Bishop, D. H. L., Carsten, E. B., Estes, M. K., Lemon, S. M., Maniloff, J., Mayo, M. A., McGeoch, D. J., Pringle, C. R., and Wickner, R. B., eds. 1999. Virus taxonomy. Rep. Int. Commit. Taxon. Viruses, 7th. Virology Division, International Union of Microbiological Societies.

Xiong, Z., Kim, K. H., Giesman-Cookmeyer, D., and Lommel, S. A. 1993. The roles of the red clover necrotic mosaic virus capsid and cell-to-cell movement proteins in systemic infection. Virology 192: 27-32.

Xoconostle-Cázares, B., Xiang, Y., Ruiz-Medrano, R., Wang, H. L., Monzer, J., Yoo, B. C., McFarland, K. C., Franceschi, V. R., and Lucas, W. J. 1999. Plant paralog to viral movement protein that potentiates transport of mRNA into the phloem. Science 283:94-98.

Zheng, H., Wang, G., and Zhang, L. 1997. Alfalfa mosaic movement protein induces tubules in plant protoplasts. Mol. Plant-Microbe Interact. 10:1010-1014. 